\title{
ENVIRONMENTAL MANAGEMENT IN THE VEGETABLE SECTOR OF MEXICO
}

\author{
L.E. PADILLA-BERNAL, A. LARA-HERRERA, A. VÉLEZ, E. REYES \& J.R. GONZÁLEZ \\ Autonomous University of Zacatecas, Mexico.
}

\begin{abstract}
The major environmental concerns of agriculture in Mexico are related to water resources and deforestation, in addition to the increasingly important issues of pesticide use, pollution, greenhouse gas emissions and soil erosion. This situation worsens in arid or semiarid regions, such as the state of Zacatecas, where the main source of water is 34 aquifers, 15 of which are overexploited. One option for reducing environmental deterioration is to encourage production units to adopt environmental management systems (EMS). These systems, however, are not well known to growers at the local or national level. The establishment of an EMS in the agricultural sector is relatively new, although it is widely used in other industrial sectors. This study determined the views, drivers and barriers to adopting an EMS in the vegetable sector of the state of Zacatecas, Mexico. A questionnaire was given to 202 technicians or owners of vegetable production units. The data were analyzed using confirmatory factor analysis and structural equation modeling. Improving access to markets was the most important driver for EMS adoption, while the lack of government support was the main barrier. The study demonstrated that views of sustainability are closely related to attitudes toward environmental management actions and environmental sustainability.

Keywords: environmental management systems, environmental protection, natural resources management.
\end{abstract}

\section{INTRODUCTION}

Agriculture is the main user of land, water, and biotic resources in most countries, greatly affecting the environment as well as society [1]. Actions that help to guarantee sustainability of the agricultural sector are of growing importance. As part of the food supply chain, agricultural enterprises face great challenges and opportunities in terms of sustainability.

The OECD [2] points out that Mexico's major environmental concerns in agriculture are related to water resources and deforestation. However, other agriculture-related issues are of growing importance: pesticide use, soil pollution caused by misuse of chemical products, greenhouse gas emissions, and soil erosion. These problems are more severe in arid or semiarid regions, such as the state of Zacatecas, where $88.3 \%$ of the farmland is rainfed and $11.7 \%$ is irrigated [3]. Water for irrigation is extracted from 34 aquifers, of which $44 \%$ are overexploited.

In this context, sustainability is a huge challenge for agricultural production units. Progress toward managing this problem can be made through transparency of the impact of the production processes of the organizations in their ecological and social ambients [4]. To 
contribute to this process, a series of mechanisms for voluntary adoption have emerged [5, 6]. One of these mechanisms is environmental management systems (EMS). A growing, but still limited, number of publications have reported theoretical and empirical study of what determines the adoption of voluntary mechanisms [7-9, among others] in non-agriculture sectors [10-12]. Moreover, in the agro-food sector, Grolleau et al. [6] analyzed the factors that determine voluntary adoption of the EMS ISO14001 or EMAS in agro-industrial enterprises in France. Hauschildt and Schulze-Ehlersb [13] analyzed the relationships between sustainability views, drivers and barriers, and procurement practices for sustainability in the German food service industry.

In the case of the agricultural sector, the first studies related to the voluntary adoption of EMSs appeared at the end of the twentieth century [14, 15]. Newbold et al. [16] studied the informal environmental management options used in agriculture. Carruthers [17] reports interviews with 40 growers and administrators of production units in Australia and New Zealand, who had either adopted a recognized EMS or had used a less formal one.

In spite of widely divulged information on EMS internationally, it is recognized that there is still little economic or social analysis of the determinants of its adoption, especially at the sector level [6]. In the particular case of Mexico, most of the agricultural production units report a lack of information on the administration of natural resources and care and protection of the environment [18]. Also, few studies report what perception agricultural producers have of the impact agriculture has on the environment, the importance farmers give to the sustainability of their production units, or their perceptions of the drivers and barriers to adoption of an EMS in this sector. This study aims to fill the gap in the information on the adoption of voluntary mechanisms by production units of the agriculture sector relative to environmental aspects. This will provide the different agencies involved in the development of the sector with information that will help them to improve their decision-making in planning short- and medium-term activities, and contribute to economic, social, and ecological sustainability of this productive sector.

The objective of this study is to determine the views on sustainability, drivers and barriers to adopting an EMS in the vegetable sector of the state of Zacatecas, Mexico. The research questions that this study answers are: What are the drivers and barriers to adoption of an EMS in the vegetable sector? What is the relationship of vegetable producers' views on sustainability to attitudes toward environmental management actions and toward environmental sustainability actions?

\section{MATERIALS AND METHODS}

\subsection{Data collection and sample definition}

The owners and technicians of four vegetable production units in the state of Zacatecas were interviewed in April and May 2014. The objective of the interviews was to identify production and environmental care and protection practices, as well as those related to environmental management among their activities. Based on these interviews and a review of literature on sustainability and environmental management, a questionnaire was designed. The questionnaire was piloted in February 2015.

The number of growers or technicians to be surveyed was determined by obtaining a representative sample of the production units (PUs) that grow vegetables. The universe for selection of the sample was the census of vegetable growers available in SAGARPA, Delegation Zacatecas (chili, tomatoes and garlic) and growers associations such as Cluster de 
Agricultura Protegida, A.C. and the Sistema Producto Tomate. The sampling method was simple random selection [19]. The sample was determined with a confidence level of $95 \%$, a level of variability of 0.25 (considering a criterion of maximum variance and a level of precision of 7\%). With the universe of 2,204 growers registered in the censuses (chili $=1,749$, tomato $=278$ and garlic $=177$ ) and adjusting with a correction factor of finite population, the minimum sample was 180 questionnaires. From March to July 2015, 207 questionnaires were applied; 202 were completely answered and were found useful for the study. The selection criteria for the PU to be surveyed were the following: (a) an open field vegetable cultivation area of $\geq 10$ hectares, or one hectare under protected agriculture, b) agricultural activity reported during 2014, and (b) willingness of the technician or owner to answer the questions. The characteristics of the PUs surveyed are presented in Table 1.

\subsection{Data analysis}

To determine producers or technicians' perception of what the drivers and barriers to adopting an EMS are, seven questions in each case were included. The participants were asked to respond on a scale of 1 to 5 where $1=$ not important and $5=$ highly important. Two analyses were performed: one grouping the PUs by whether or not they had some kind of certification and the other by whether or not they exported. To determine the relationships of views on sustainability (VSUS) to attitude toward environmental management actions (AEMS) and

Table 1: Characteristics of the surveyed production units $(n=202)$.

\begin{tabular}{llr}
\hline Total planted area of the PUs and & Open field (ha) & $8,568.8$ \\
type of cultivation & Protected agriculture (ha) & 415.5 \\
& Total (ha) & $8,984.2$ \\
Type of cultivation in the PUs & Only field cultivation & 123 \\
& Only protected agriculture & 36 \\
& Open field cultivation and protected & 43 \\
& agriculture & 76 \\
Market type where the PUs sell & Local & 64 \\
their produce & National & 54 \\
& Local and national & 1 \\
& Local, national and international & 7 \\
Certifications & Nacional and international & 37 \\
Formal education of the survey & PU has some sort of certification & 165 \\
participants & PU has no certification & 38 \\
& Elementary school & 44 \\
& Secondary school & 31 \\
& High School & 76 \\
& Bachelor's degree & 13 \\
\hline
\end{tabular}


194 Environmental and Economic Impact on Sustainable Development

toward environmental sustainability actions (ASUS), a first order confirmatory factor analysis (CFA) model was applied, considering the proposal of Epstein and Roy [20] (Fig. 1). The indicators or variables observed of the views on sustainability (VS1-VS16) were adapted from Rankin et al. [21] and Hauschildt and Schulze-Ehlersb [13]. The indicators of environmental management actions (AE1-AE8) were obtained from SENASICA [22, 23], and environmental sustainability actions (AS1-AS7) from Carruthers [17]. A 1 to 5 scale was used to measure each of the indicators in which $1=$ not done or don't agree, and $5=$ done or totally agree. The initial first-order CFA model was run to test the interrelationship of the factors VSUS, AEMS and ASUS, as well as to obtain the representability of the indicators or observed variables attributed to each factor (latent construct), avoiding unreliable and redundant indicators.

According to the Mardia index, the data follow a normal multivariate distribution [24]. Estimation of the parameters in the model was determined using Maximum Likelihood estimation. The items that correlated highly were eliminated from the model to prevent multicollinearity and because they were not considered representative of the factor. Another criterion applied to reduce observed variables was index modification to detect mis-specified error covariances and items. The applications were performed using AMOS v23 software. Tables 2-4 present the definitions of the variables of the analyzed factors.

\section{RESULTS}

\subsection{Drivers and barriers to adoption of an EMS in the vegetable sector}

The adoption of an EMS is multidimensional and refers to different factors, such as pressure from consumers and other agents in the value chain, the desire to improve performance and implement an integrated management system $[6,25]$. These factors, however, change over time and vary with changes in individual circumstances and context.

Survey participants considered facilitating access to domestic and international markets (4.51) and reducing production costs (4.38) the most important motivations for EMS adop-

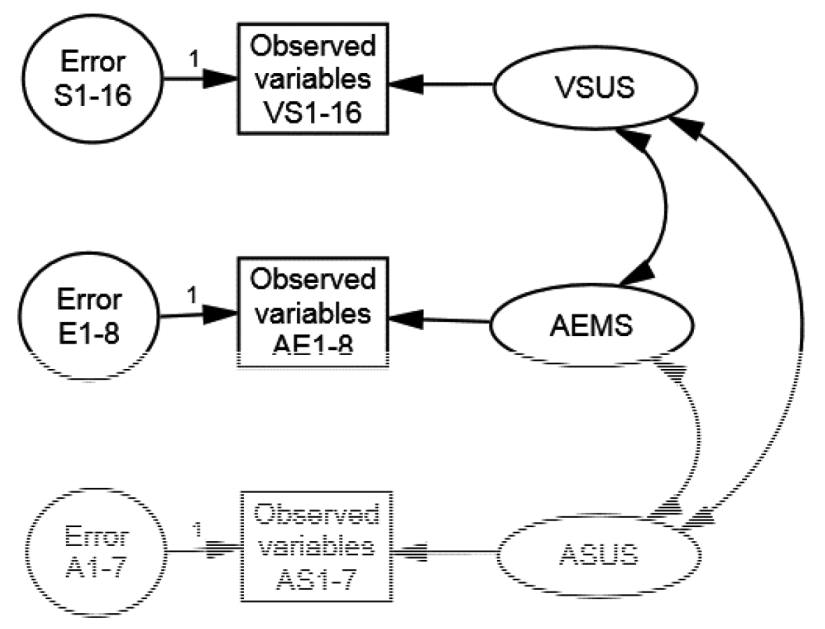

Figure 1: Initial confirmatory factor analysis model. 
Table 2: Variables evaluated in the factor "Views of sustainability".

\begin{tabular}{|c|c|c|}
\hline Factor & $\begin{array}{l}\text { Variable } \\
\text { observed }\end{array}$ & Variable definition \\
\hline \multirow{16}{*}{$\begin{array}{l}\text { Views of } \\
\text { sustaintability } \\
\text { (VSUS) }\end{array}$} & VS1 & Complying with laws and standards \\
\hline & $\mathrm{VS} 2 *$ & Producing safe products for consumers. \\
\hline & VS3 & A way to strengthen image \\
\hline & VS4* & A strategy for cost savings \\
\hline & VS5* & $\begin{array}{l}\text { A belief that leads to caring for and protecting the environ- } \\
\text { ment }\end{array}$ \\
\hline & VS6 & A strategy for improving market position \\
\hline & VS7* & A way to impact employee satisfaction \\
\hline & VS8 & An opportunity for new revenue \\
\hline & $\mathrm{VS} 9 *$ & A set of values that guide the work of the PU \\
\hline & VS10 & A strategy to improve the PU's position in the long run \\
\hline & VS11 & A method of risk management \\
\hline & VS12* & A value integrated into the PU \\
\hline & VS13* & A way of being solidary with other growers \\
\hline & VS14* & Addressing hunger and societal welfare \\
\hline & VS15 & $\begin{array}{l}\text { Reducing impact on the environment to preserve it for the } \\
\text { future }\end{array}$ \\
\hline & VS16* & An integral part of the core PU \\
\hline
\end{tabular}

* Removed from the model.

Scale: from $1=$ does not apply or does not agree to $5=$ in complete agreement.

tion, followed by improving PU sustainability (4.21) (Table 5). These responses are congruent with the findings of Carruthers [17]; Carruthers and Vanclay [25]. The motivation considered the least important was compliance with environmental protection standards (3.76).

Regarding the barriers to EMS adoption [6, 17, 25, 26], Table 6 presents the mean and standard deviation of the perception of the interviewees. Lack of government support (4.17) and additional expenses of monitoring, training, infrastructure and equipment (3.91) were the two indicators that, on average, the survey participants named as the most important barriers to EMS adoption. Another two barriers, with values above 3.75 were not knowing how to quantify environmental damage (3.84) and ignorance of environmental aspects of their management (3.78). Referring to the latter two indicators, Carruthers and Vanclay [25] point out that EMS users know more about their enterprise's impacts and look for solutions more actively than non-EMS users.

Lack of financial resources and ignorance of environmental problems are the most important barriers to adopting an EMS in the vegetable production units of Zacatecas. These two aspects were given more importance than time and work required by the activities related to environmental management. Carruthers and Vanclay [25] also considered that costs, concerns about the necessary skills, time, and resourcing are common barriers for EMS adoption and other practices. 
196 Environmental and Economic Impact on Sustainable Development

Table 3: Variables evaluated in the factor "Attitude toward environmental management actions".

\begin{tabular}{|c|c|c|}
\hline Factor & $\begin{array}{l}\text { Variable } \\
\text { observed }\end{array}$ & Variable definition \\
\hline \multirow{8}{*}{$\begin{array}{l}\text { Attitude toward } \\
\text { environmental } \\
\text { management } \\
\text { actions (AEMS) }\end{array}$} & AE1 & A record of inputs used during crop development \\
\hline & AE2 & $\begin{array}{l}\text { Application of documented procedures related to worker } \\
\text { hygiene, good use and management of agrochemicals, } \\
\text { harvest, packing, worker training, among others. }\end{array}$ \\
\hline & $\mathrm{AE} 3 *$ & $\begin{array}{l}\text { Planning activities required for protecting the environ- } \\
\text { ment }\end{array}$ \\
\hline & AE4* & $\begin{array}{l}\text { A written policy for dealing with empty agrochemical } \\
\text { containers. }\end{array}$ \\
\hline & AE5 & $\begin{array}{l}\text { A manual of procedures for storing pesticides, handling } \\
\text { water for spraying, containing spills, pesticide classifica- } \\
\text { tion and toxicology, among others. }\end{array}$ \\
\hline & AE6* & $\begin{array}{l}\text { A defined organizational structure and organization } \\
\text { manuals }\end{array}$ \\
\hline & $\mathrm{AE7} *$ & $\begin{array}{l}\text { Application of a documented program of pollutant sur- } \\
\text { veillance. }\end{array}$ \\
\hline & AE8* & $\begin{array}{l}\text { Adoption of a System of Contamination Risks to prevent } \\
\text { pesticide contamination. }\end{array}$ \\
\hline
\end{tabular}

* Removed from the model.

Scale: from $1=$ not done to $5=$ always done.

Table 4: Variables evaluated in the factor "Attitude toward actions relating to environmental sustainability".

\begin{tabular}{lll}
\hline Factor & Variable observed & Variable definition \\
\hline Attitude toward & AS1 & Water \\
actions relating & AS2 & Soil \\
to environmental & AS3* & Biodiversity \\
sustainability (ASUS) & AS4 & Agrochemicals \\
& AS5 & Pollution \\
& AS6 & Waste management \\
& AS7 & Business environmental management \\
\hline
\end{tabular}

* Removed from the model.

The value of the variable was the average of four items evaluated on a scale from $1=$ not done or not applicable to $5=$ always done or applied.

It is notable that $37(18.3 \%)$ of the studied PUs have some type of certification related to safety or quality of their products, environmental protection and/or worker well-being, such as PrimusLabs, Buenas Prácticas Agrícolas and BUMA. The other 165 (81.7\%) do not have any certification. Of the group of certified PU, eight ship their products to the international 
Table 5: Drivers to adoption of an EMS.

\begin{tabular}{llc}
\hline Drivers & Mean & $\begin{array}{c}\text { Standard } \\
\text { deviation }\end{array}$ \\
\hline Consistent with personal principles & 3.92 & .989 \\
Prevent harm to workers & 4.01 & .990 \\
Improve the production unit's image & 4.11 & .978 \\
Improve production unit sustainability & 4.21 & .886 \\
Reduce production costs & 4.38 & .902 \\
Facilitate access to domestic and international markets & 4.51 & .806 \\
Compliance with environmental protection standards & 3.76 & .963 \\
\hline
\end{tabular}

Table 6: Barriers to adoption of an EMS.

\begin{tabular}{lcc}
\hline Barriers & Mean & Standard deviation \\
\hline $\begin{array}{l}\text { Ignorance about environmental aspects } \\
\text { and their management }\end{array}$ & 3.78 & 1.122 \\
$\begin{array}{l}\text { Lack of knowledge on how to quantify } \\
\text { environmental damage }\end{array}$ & 3.84 & 1.086 \\
$\begin{array}{l}\text { Additional expenses for monitoring, } \\
\text { training, infrastructure and equipment }\end{array}$ & 3.91 & 1.168 \\
$\begin{array}{l}\text { Lack of PU personnel trained in actions } \\
\text { that help to protect the environment }\end{array}$ & 3.71 & 1.054 \\
$\begin{array}{l}\text { Lack of government support } \\
\text { Too much paperwork and document } \\
\text { requirements }\end{array}$ & 4.17 & 1.090 \\
$\begin{array}{l}\text { Not sufficient time to plan and imple- } \\
\text { ment environmental actions }\end{array}$ & 3.26 & 1.187 \\
\hline
\end{tabular}

market. The $t$ test for the difference between two means demonstrated that there are significant differences ( $\mathrm{p}$-value $\leq 0.05$ ) between certified and uncertified PU in average values of both drivers (certified $=4.52$ and uncertified $=4.04$ ) and barriers (certified $=3.45$ and uncertified $=3.76$ ) to adoption of an EMS. The same $t$ test also found differences ( $p$-value $<0.05)$ between the average value of the drivers of the PU that export (4.66) and those that do not (4.11). However, in the case of the barriers, the latter two groups were not significantly different $(\mathrm{p}$-value $=0.214$ ) in their opinion regarding the barriers $($ exporters $=3.39$ and non-exporters $=3.72$ ).

3.2 Views on sustainability and attitude toward environmental management actions and toward environmental sustainability actions

A summary of the selected fit indices to evaluate the hypothesized and the end model is presented in Table 7. The values obtained for the initial first-order EMS model in three key 
198 Environmental and Economic Impact on Sustainable Development

Table 7: Goodness-of-fit indices $(\mathrm{n}=202)$.

Initial first-order

Final first-order

EMS CFA model

EMS CFA model

Number of latent variables

$\begin{array}{rr}3 & 3 \\ 31 & 15 \\ 431 & 87\end{array}$

Degrees of freedom (df)

Total number of observed variables

1041.050

143.787

$\mathrm{X}^{2}$ Statistics

0.000

0.000

$\mathrm{p}$-value

2.415

1.653

Normed Fit Index (NFI)

0.780

0.921

Comparative Fit Index (CFI)

0.857

0.967

0.084

0.057

(RMSEA)

Closeness of fit (PCLOSE)

0.000

0.235

Expected cross-validation index (ECVI)

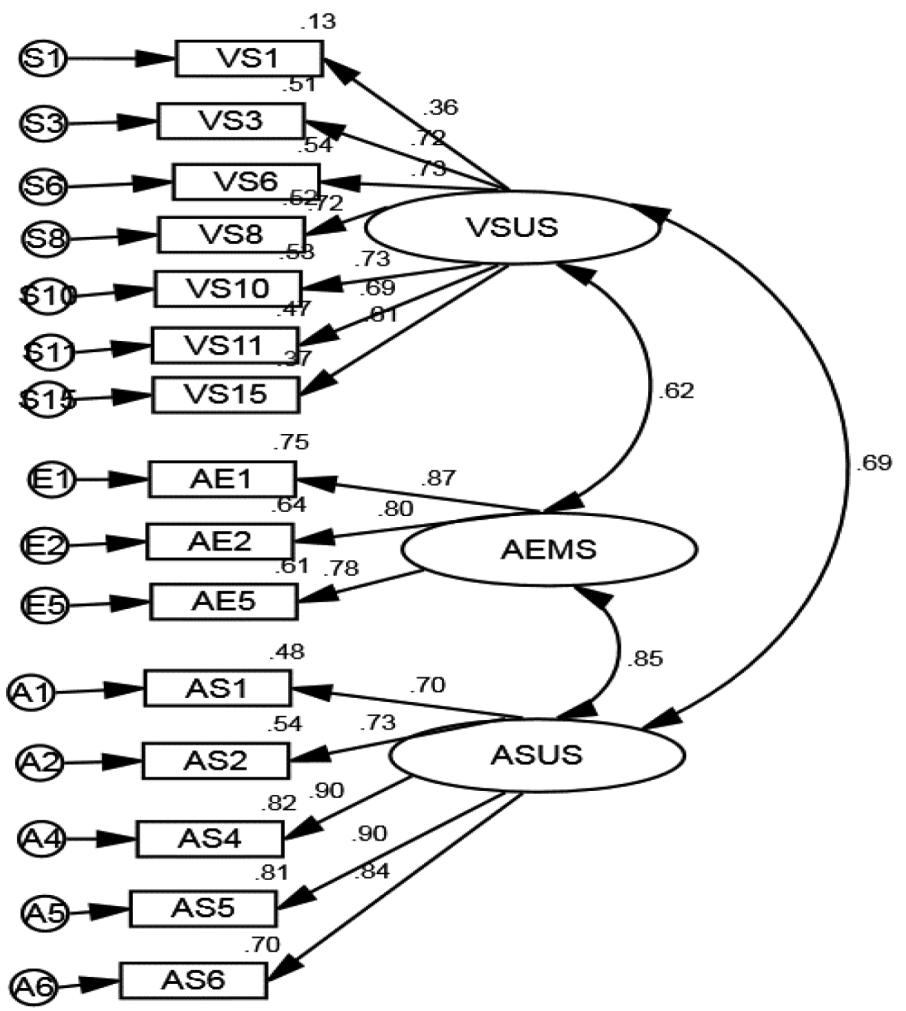

Figure 2: Final first-order EMS CFA model. 
indices were $=1041.05, \mathrm{CFI}=0.857, \mathrm{RMSEA}=0.08$, indicating a need to modify the model to improve the fit to acceptable levels (e.g., CFI $>0.90$ and RMSEA $\leq 0.08$ ). We thus proceeded to eliminate redundant or highly correlated items in each construct under the criteria indicated above. As recommended by Byrne [24], only one parameter was changed at every step. The Cronbach Alpha coefficient was used to measure scale reliability of the constructs. The values obtained were VSUS $=0.838$, AEMS $=0.859$ and ASUS $=0.915$. Coefficients with Cronbach Alpha values of 0.70 or higher are for narrow constructs and 0.55 or higher for moderately broad constructs [27].

The final first-order EMS CFA model is presented in Fig. 2. Goodness-of-fit statistics related to this model were substantially satisfactory $(=143.78, \mathrm{CFI}=0.967, \mathrm{RMSEA}=0.057)$ (Table 7). All the structural parameter paths were statistically significant ( $\mathrm{p}$-value $<0.001$ ). All the inter-factor correlations were positive, significant ( $p$-value $<0.001$ ), and above 0.60 , suggesting the hypothesized relation between factors: views of sustainability and attitude toward environmental management actions and toward environmental sustainability.

\section{CONCLUSIONS}

The growers manifested that they had little information on EMS application in agriculture and exhibited uncertainty in determining the benefits and costs of its implementation. The most mentioned driver for adoption of an EMS was that it facilitates access to domestic and international markets, while the most mentioned barrier was lack of government support.

The fact that a production unit had the experience of achieving certification related to safety or quality of their products, environmental protection, and/or well-being of their workers significantly differentiated the opinions of the growers or technicians regarding drivers and barriers to adopting an EMS. The same occurred with the drivers of the PU oriented toward international markets versus those that sell on the domestic market. However, between these two groups of PUs there is no difference in opinion regarding the barriers to EMS adoption. It was demonstrated that views on sustainability are positively related to attitude toward environmental management actions and to attitude toward environmental sustainability.

\section{REFERENCES}

[1] Aigner, D.J., Hopkins, J. \& Johansson, R., Beyond compliance: sustainable business practices and the bottom line. American Journal of Agricultural Economics, 85(5), pp. 1126-1139, 2003. http://dx.doi.org/10.1111/j.0092-5853.2003.00519.x

[2] OECD, Desempeño Ambiental de la Agricultura desde 1990. Reporte Principal, OECD: Paris, pp. 6-10, 2008.

[3] Servicios de Información Agroalimentaria y Pesquera (SIAP-SAGARPA). Producción anual, available at http://www.siap.gob.mx/

[4] Porter, M.E. \& Kramer, M.R., Strategy and society. The link between competitive advantage and corporate social responsibility. Harvard Business Review, 89, pp. 1-17, 2006.

[5] Khanna, M., Non-mandatory approaches to environmental protection. Journal of Economic Surveys, 15(3), pp. 291-324, 2001. http://dx.doi.org/10.1111/1467-6419.00141

[6] Grolleau, G., Mzoughi, N. \& Thomas, A., What drives agrifood firms to register for an environmental management system? European Review of Agricultural Economics, 34(2), pp. 233-255, 2007.

http://dx.doi.org/10.1093/erae/jbm012 
200 Environmental and Economic Impact on Sustainable Development

[7] Arora, S. \& Cason, T., An experiment in voluntary environmental regulation: participation in EPA's 33/50 program. Journal of Environmental Economics and Management, 28, pp. 271-286, 1995. http://dx.doi.org/10.1006/jeem.1995.1018

[8] Videras, J. \& Alberini, A., The appeal of voluntary environmental programs: which firms participate and why? Contemporary Economic Policy, 18(4), pp. 449-461, 2000. http://dx.doi.org/10.1111/j.1465-7287.2000.tb00041.x

[9] Del Brío, J.A. \& Junquera, B., Influence of the perception of the external environmental pressures on obtaining the ISO 14001 standard in Spanish industrial companies. International Journal of Production Research, 41(2), pp. 337-348, 2003. http://dx.doi.org/10.1080/0020754021000024175

[10] Darnall, N., Gallagher, D.R., Andrews, R.L. \& Amaral, D., Environmental management systems: opportunities for improved environmental and business strategy? Environmental Quality Management, 9(3), pp. 1-9, 2000. http://dx.doi.org/10.1002/1520-6483(200021)9:3<1::AID-TQEM1>3.0.CO;2-L

[11] Nash, J. \& Ehrenfeld, J.R., Factors that shape EMS outcomes in firms (Chapter 3). Regulating from the Inside. Can Environmental Management Systems Achieve Policy Goals? ed. C. Coglianese \& J. Nash, Resources for the Future: Washington, DC, pp. 61-81, 2001.

[12] Florida, R. \& Davison, D., Why do firms adopt environmental practices (And do they make a difference)? (Chapter 4). Regulating from the Inside. Can Environmental Management Systems Achieve Policy Goals? ed. C. Coglianese \& J. Nash, Resources for the Future: Washington, DC, pp. 82-104, 2001.

[13] Hauschildt, V. \& Schulze-Ehlersb, B., An empirical investigation into the adoption of green procurement practices in the German food service industry. International Food and Agribusiness Management Review, 17(3), pp. 1-32, 2014.

[14] Mech, T., Enviornmental management systems implementation in agriculture. Identifying and overcoming barriers. RIRDC Publication 06/05: Australia, pp. 3-4, 2006.

[15] Williams, T., Environmental management in agriculture and the rural industries: voluntary approaches to sustainability and globalization imperatives. RIRDC. No. 09/023, Australian Government, Union Offset Printing, Canberra, pp. 1-66, 2009.

[16] Newbold, M.J., Lewis, K.A., Tzilivakis, J., Finch, J., Kähö, T.M., Skinner, J.A. \& Bardon, K., Options for informal environmental management: the agricultural industry highlighted. Eco-Management and Auditing, 4(1), pp. 22-27, 1997. http://dx.doi.org/10.1002/(SICI)1099-0925(199703)4:1<22::AID-EMA55>3.0.CO;2-9

[17] Carruthers, G., Adoption of environmental management systems in agriculture. An analysis of 40 case studies. Australian Government, No. 05/032: Canberra, pp. 1-117, 2005.

[18] Secretaría de Medio Ambiente y Recursos Naturales (SEMARNAT), La gestión ambiental en México. SEMARNAT: México, pp. 241-263, 2006.

[19] Mendenhall, W. \& Reinmuth, J., Estadística para administración y economía, Wadsworth International/Iberoamericana: Estados Unidos, pp. 515-520, 1981.

[20] Epstein, M.J. \& Roy, M.J., Sustainability in action: Identifying and measuring the key performance drivers. Long Range Planning, 34(5), pp. 585-604, 2001. http://dx.doi.org/10.1016/S0024-6301(01)00084-X

[21] Rankin, A., Gray, A.W., Boehlje, M.D. \& Alexander, C., Sustainability strategies in U.S. agribusiness: understanding key drivers, objectives, and actions. International Food and Agribusiness Management Review, 14(4), pp. 1-20, 2011. 
[22] Servicio Nacional de Sanidad, Inocuidad y Calidad Alimentaria (SENASICA). Buen Uso y Manejo de Agroquímicos, available at www.fps.org.mx/, México, 2015.

[23] Servicio Nacional de Sanidad, Inocuidad y Calidad Alimentaria (SENASICA). Lineamientos generales para la operación y certificación de sistemas de reducción de riesgos de contaminación en la producción primaria de alimentos de origen agrícola, SAGARPA: Mexico, 2010.

[24] Byrne, B., Structural equation modeling with AMOS. Taylor and Francis Group, LLC: New York, pp. 53-127, 2010.

[25] Carruthers, G. \& Vanclay, F., The intrinsic features of environmental management systems that facilitate adoption and encourage innovation in primary industries. Journal of Environmental Management, 110, pp. 125-134, 2012. http://dx.doi.org/10.1016/j.jenvman.2012.06.003

[26] Williams, H., van Hooydonk, A., Dingle, P. \& Annandale, D., Developing tailored environmental management systems for small businesses. Eco-management and Auditing, 7(3), pp. 106-113, 2000. http://dx.doi.org/10.1002/1099-0925(200009)7:3<106::AID-EMA130>3.0.CO;2-C

[27] Curkovic, S., Environmentally responsible manufacturing: The development and validation of a measurement model. European Journal of Operational Research, 146(1), pp. 130-155, 2003.

http://dx.doi.org/10.1016/S0377-2217(02)00182-0 